\title{
Religious and Political Facets of Fundamentalism: Socio-philosophical Analysis
}

\author{
Alexey Volobuev \\ Department Sociology, history and philosophy \\ Financial University under the Government of the Russian Federation \\ Moscow, Russia 125993 \\ E-mail: urticaferox@yandex.ru
}

\begin{abstract}
The article is devoted to the socio-philosophical analysis of a phenomenon of fundamentalism, its religious and political facets. Historically, the concept "fundamentalism" has appeared in hermeneutics and had highly specialized value, designating literal reading of the religious text. Having arisen among the American Protestants as opposition of religious modernization and liberalization, fundamentalism quickly became significant social and political force. Fundamentalism has reached the peak of the popularity with a minus sign after the creation of the infamous Islamic State. At the same time, the subject of fundamentalism isn't exhausted by religious extremism: really, in the modern world there is a set of forms of this many-sided phenomenon, including ethnoreligious fundamentalism, market fundamentalism and even feministic fundamentalism. The fundamental bases of this phenomenon and its multifaceted nature are analyzed in the article. The article reveals the essence of fundamentalism in the context of the process of globalization. The author demonstrates that fundamentalism as a whole is not synonymous with traditionalism, but is one of the possible answers of religious consciousness to the rapid process of modernization.
\end{abstract}

Keywords-Salafism; fundamentalism; Islam; evangelical churches; religion; philosophy of religion; religious studies; modernization

\section{INTRODUCTION}

"Too bad we are so relevant" [1] - this is the title of one of the last interviews of Martin Marty, a researcher who from 1987 to 1995 led the largest fundamentalism research project in the history "Fundamentalism project", which resulted in the publication of a series of scientific works of five volumes.

The term "fundamentalism" is currently well-known both throughout academic community and masses of people. Thus, Anthony Giddens, professor at London School of Economics and Political Science, characterizes the fundamentalist "... as a person who in principle refuses to enter into a dialogue, who considers his way of life to be perfect and worthy, and a foreign one - relatively inferior and unworthy," and he cautiously adds: "This is very dangerous: the more we have to live in a world where it is necessary to get along with people who are not like us, the more dangerous this principle is becoming. [2]. How can such a phenomenon be possible in the modern world of rapid progress and what does it mean? In order to find an answer to these questions, we need to follow the formation and development of religious fundamentalism, highlighting its socio-philosophical aspects.

As a rule, the emergence and development of some ideology will soon lead to the emergence of an oppositely directed one. The ideas of progress, modernization, modernizing all aspects of life have shaped the ideology of modernity already in the Age of Enlightenment, including the desire to modernize religion. The key messages of the latter were the desire to purge religions of superstition, singling out "rational" grain in them: first of all, ethics. It should be noted that religious modernization was not limited to the Christian world: Islamic religious reformers, such as Mohammed Iqbal, began to exert a significant influence on contemporary society in the 19th century. The opposite tendency, which meant opposing any changes in the religious life of society and returning to its hypothetical "initial" state, took shape somewhat later.

Religious fundamentalism is often identified with traditionalism, which is completely untrue, despite some intersections between the two concepts. If traditionalism is associated with the desire to preserve what is available, fundamentalism is based on longing for what has already been lost and for renewal through a return to the roots.

\section{RELIGIOUS FACET OF FUNDAMENTALISM}

The term appeared in the second half of the nineteenth century in American religious studies to denote the position of those members of evangelical churches who did not accept the liberal interpretation of the Bible and the modernization of Christian doctrine. This term designated a wide range of various associations of the American Protestants which resisted to processes of religious modernization and liberalization, protecting what, according to them, was "fundamental" values of Christian belief. Literal interpretation of the Bible as sacral text, the belief in creation of the world by the Lord, belief in bible miracles, such as immaculate conception and Resurrection in fleshes were these "bases" ("fundamentals"). These principles have been established during the so-called "Niagara conferences" of North American evangelists in 1885 The key princeiples were: 
- the sacred texts are the source of absolute and infallible truth;

- the Biblical miracles should be interpreted literally;

- the allegorical interpretations of the modernists are not acceptable.

American fundamentalists became widely known for their intransigent struggle against evolutionary doctrine, especially after the adoption of the Act of Butler (1925, Tennessee, USA), which prohibited the teaching in schools and universities of any non-biblical theories of human origin, in particular, the theory of evolution.

Manichean perception of the world is inherently charactericstic to fundamentalists, considering themselves participants in the struggle between good and evil in the very literal sense, or, for example, sharing the view that the course of history is predicted in biblical prophecies.

Thirdly, the fundamentalists were distinguished by a very aggressive, militant attitude toward any manifestations of the modernization of religion (both theology and social life) and by the tendency to demonize their opponents. They considered themselves to be "true Christians of biblical faith."

It should be noted that the anti-modernist attitude of the American Evangelical churches had a significant impact on the entire Protestant part of American society (i.e., almost on the whole society): "In the US, there is a very fundamentalist society, similar in degree of religious fanaticism to Iran. For example, seventy-five percent of the US population, I think, simply believe in the devil "- sums up Noam Chomsky [3].

Thus, religious fundamentalism appeared in the US as a reaction to the modernization of theology and religious life from some members of the Evangelical churches, and this was not simply a rise in traditionalism, but fundamentalism shaped its own paradigm and self-identification system.

Islamic revolution of 1978 in Iran proved to be another milestone in development of fundamentalism. Since 1978, fundamentalism has been actively studied not only by religious scholars: the attention of political scientists around the world is also attracted to this phenomenon, which, at first glance, does not fit into the positivist picture of the development of society.

We won't be wrong to evaluate Islamic fundamentalism as the most well-known (and, probably, infamous) form of religious fundamentalism. For example, one of the Saudioriginated teachings, Salafism, serves as an ideological basis of the vast majority of modern Islamist trends and organizations. Salafism is not just a theological school, it is the totalitarian political ideology of a theocratic state. "The slogan al-Islam hua al-hal" ("Islam is the solution") means that in order to restore order in the Muslim world, to eradicate social injustice, immorality and corruption, to eliminate "unjust rulers", as well as to protect against the harmful effects of foreign cultural and behavioral models of the West, it is necessary, first of all, to purify Islam itself from harmful layers, to return to the unclouded origins of this religion» [4]. Salafists of the most diverse kind proceed from the belief that the Islamic world is in a state of decline caused by the retreat from traditional values and ethics of Islam, the rejection of the Islamic ethical and legal system, the Islamic Sharia. Fundamentalists demand a return to the laws, norms and values of Islam, thus building a socially just state. At the same time, fundamentalists often gravitate toward a kind of pan-Islamism, because Islamic state must unite the disparate national entities of the Islamic world or even the entire Muslim community, the umma.

Besides Christianity and Islam, we can meet use of the term "fundamentalism" in relation to Judaism. In this case the concept, in most cases, is used for designation of ultra orthodox currents and doctrines in Israel (in rare instances outside this state) which persistently demand judaizing implicitly to subordinate the life to the Writing letter (and meaning not only the Pentateuch, but also the Talmud and Mishna), extremely not tolerantly belonging to any manifestations of a deviation from the rigoristic line. As well as all fundamentalists, Judaic ulraortodoksa show public activity: in Israel periodically there are attacks of ulraortodoksalny students on the fellow citizens working in the Sabbath. Ultraorthodoxes also intolerantly treat any manifestations of religious liberalism and the liberal social changes, for example, they are extremely intolerant in relation to open homosexuals. Besides the above, Judaic fundamentalists live in constant expectation of the Messiah which arrival they perceive literally as something that has to occur in the near future [6, p. 189].

In Russian history, we can also recall a similar process, which occurred earlier in the times of schism. The Russian Orthodox Church faced the challenges of modernization and Westernization, the response to which from church hierarchs was energetic reforms. They were aimed at renewal of religious life through its rationalization, centralization, significant investments in infrastructure, the inspiration of new energy in it, the struggle against "disorganization" and archaisms. Extremely energetic reforms of Patriarch Nikon caused an extremely negative reaction in a part of society: the response of consciousness to the flow of change was the flight from these very changes, the flight of the Old Believers into an idyllic past. Raskolniki in Russian history are very similar to religious fundamentalists.

Modern Russian Orthodoxy also has certain features of fundamentalism. This is both anti-ecumenism and extreme statism: the ROC opposes the Russian state identity to the abstract model of the "sinful" West, and the general attitude of opposing themselves to the liberal socio-political model of a globalized society, especially to the market economy with its social injustice [5]. Therefore, the Russian Orthodox fundamentalism is also interwoven with the political agenda.

\section{POLITICAL FACET OF FUNDAMENTALISM}

At all variety of forms of religious fundamentalism it would be wrong to be limited to the description only of this side of the phenomenon. Already in the description of an Islamic fundamntalizm the totality of Salafism is evident: all parties of public life and the identity of the Muslim have to be subject to Islamization. Here in general it becomes 
difficult to separate religion from policy. Perhaps, fundamentalism isn't exhausted by a religious form? Really, besides religious, recently distribution was gained also by political fundamentalism. To understand on what basis we use initially hermeneutical term for the description of the secular, in general, phenomenon, we will give some most striking examples of this phenomenon. But why is fundamentalism, unlike traditionalism, a phenomenon related to modernity? The fact is that the fundamentalists not only strive to preserve their way of life (like the Old Believers), they create and preach their ideal of life, which they put in the past, thus creating a kind of "false memory" about the idealized past. Then the fundamentalists seek to extend it to the modern society through propaganda in the media. That is why fundamentalism is inclined to become a political ideology.

Fundamentalism is not a direct antithesis to modernity, on the contrary, fundamentalists borrow from modern time those means which are considered necessary to achieve their goals.

"Fundamentalism is by no means synonymous with the term" traditionalism ", it is rather one of the possible ways of renewing tradition, combining the reworked, idealistically presented elements of tradition and innovation - to such an extent to which they are necessary to establish the ideal. fundamentalism is related to Tradition, but it is not limited to it, it is always the answer of the mythologized Tradition to the challenge of Modern Time [7].

Thus, there is no contradiction in the fundamentalists' use of rational thinking, media and modern technologies, as there is no contradiction in the striving to acquire material wealth and power for the sake of an ideal goal. "Thus, religious fundamentalism and religious modernism are ambivalent phenomena which are able to actively interact with each other and come together in their content [8].

Since fundamentalism appeals to social injustice, corruption and lawlessness as inherent features of modernization and globalization, this ideology turns out to be an expression of the social protest of the masses.

Another contradiction that shapes political affinity of fundamentalists is that between fundamentalism and liberal values. The demand for obedience to the will of the majority, the basic one for liberal democracy, directly contradicts the ideology of Islamic fundamentalism: "they do not vote for God, they obey God"[9]. But the absence in fundamentalist ideologies of any productive social and economic program that transcends the redistribution of wealth makes possible the integration of liberal values even into the consciousness of a religious person, since this lacuna is not filled with Islamic ideology. Therefore, a balanced religious policy aimed at supporting the moderate and discrediting extremist trends of Islamic fundamentalism allows us to direct the social protest of the marginalized masses of the population into the traditional religious channel, while coping with dangerous extremist tendencies, especially support for radical Salafi trends from abroad. It is important not note that being a fundamentalist does not equal to being an extremist. For instance, among the Islamic fundamentalist organizations, there are a lot of them preaching peaceful policies and charities. For example, "the organization of Islamic cooperation (OIC), which opposes racism and colonialism, RAIS (Russian Association of Islamic Consensus) and OIC (Organization of Islamic Cooperation), which work for the unity of Muslims through good deeds (establishment of the Fund for Assistance to Victims of Extremists, construction of mosques, work with youth, etc.) ", as well as numerous charitable organizations [10].

\section{CONCLUSION}

We conclude that fundamentalism is both a form of religious outlook and a political ideology at the same time, being an aggressive reaction to the modernization and rationalization of religious life and society. The essence of this reaction lies in the fact that in today's disequilibrium society of risk, turbulence and open future, religious fundamentalism presents a simplified alternative in the form of abandoning modernization as such, seeing the ideal in an idyllic simplistic picture that supposedly had a place in the past [11]. Instead of unraveling the complex tangle of social and economic problems, fundamentalism puts forward the idea of returning to the previous state of society, when these problems simply did not exist. "Islam is the solution!"- is one of the popular slogans of the Islamist organization "Muslim Brotherhood".

Any form of fundamentalism by nature has irrational character, appealing to uneasiness, fear, the need for security and fear, quite natural to the living being, of the unknown. Fundamentalism is a form of outlook therefore it isn't limited only to religion, and can prove in many forms of public life, and first of all in policy. Thereof, the fragmented studying of his separate forms can't give a full-fledged picture of this public phenomenon: for example, we will hardly be able to understand what moves supporters of Islamic radical currents, having concentrated only on a religious part of the doctrine. For adequate understanding of this phenomenon it is necessary to study fundamentalism as an outlook form in general [12].

Being an active reformer, fundamentalist does not see itself outside the public and political life and, often, considers it necessary to restructure society in all its manifestations in accordance with the ideal of its tradition. The crucial element of syncretic thinking is associated with the antithesis "sacral - profane". Modernization has consistently deprived the sacredness of almost all spheres of life, trying, however, to replace it by human rights and freedoms as sacred ones, but the success of this replacement raises great doubts. A fundamentalist often perceives desacralization as desecration and he reacts aggressively [14]

The profound well-grounded understanding of the globalized world is impossible if the "reverse side: of globalization is discarded. 


\section{REFERENCES}

[1] Too Bad We're So Relevant: The Fundamentalism Project Projected http://www.illuminos.com/mem/selectPapers/fundamentalismProject. html

[2] A.Giddens. What tomorow: fundamentalism or solidarity // Patriotic scripts. 2003, № 1. URL: http://www.strana-oz.ru/2003/1/chtozavtrafundamentalizm-ili-solidarnost

[3] N.Chomsky. How the world works. Moscow, AST, 2014, 448 p.

[4] G.I.Mirsky. Political Islam and the Western society. Polis, 2002, №1, pp. 78-86.

[5] E.A.Stepanova. Fundamentalism and the identity mania. Annual scientific magazine of the Institute of philosophy and law of Ural section of RAS. 2008, №8, pp. 94-116.

[6] Israel Shahak. Jewish Fundamentalism in Israel.London, Pluto Press, $2004-210$ p.

[7] A.I.Yakovlev. Religious factor of international policy in the globalization era: from secularization to fundamentalism. Moscow University Herald, S.25. International relations and global policy. 2013, № 4. P. 4-37.

[8] D.A.Golovushkin. Religious fundamentalism/ religious modernism: conceptual enemies or ambivalent phenomena? PSTGU Herald I: Theology. Philosophy, 2015, № 1(57), pp. 87-97.

[9] M.Kramer. Where Islam and democracy part ways. Democracy in the Middle East: Defining the Challenge. Washington, 1993, p.257.

[10] I.S.Shegaev. Religious fundamentalism: definition and origins. Almanac of modern science and education. Tambov: Gramota, 2014. № 1 (80). PP. 133-136.

[11] Mikhail Oseledchik, Marina Ivleva, Vitaly Ivlev. Knowledge as a non-equilibrium dynamic system // "Proceedings of the 2017 2nd International Conference on Contemporary Education, Social Sciences and Humanities". (ICCESSH 2017). Part of the series ASSEHR. Moscow, Russia. V.124. P.1-5.

[12] Alexey Chernyak. Proceedings of the 2016 International Conference on Contemporary Education, Social Sciences and Humanities // Proceedings to the International Conference on Contemporary Education, Social Sciences and Humanities (ICCESSH 2016), Atlantis Press, 2016 Pp. 604-610

[13] Philip Tagirov. Symbolic violence and the Other in cross-cultural field (some remarks on R. Girard's and J. Baudrillard's theories). Proceedings of the 2016 International Conference on Arts, Design, and Contemporary Education. (ICADCE 2016) Advances in Social Science, Education and Humanities Research». C. 1268 - 1273

[14] Elena Kuzina. Philosophy of Education by T. Jefferson // Proceedings of the 3rd International Conference on Contemporary Education, Social Sciences and Humanities (ICCESSH 2018) Pp. 89-92 